\title{
Pengaruh Kompetensi terhadap Motivasi Pegawai Kantor Dinas Perhubungan Provinsi Jambi
}

\author{
Kasiyati Yunita Wulansari \\ Sekolah Tinggi Ilmu Ekonomi Graha Karya, Muara Bulian
}

\begin{abstract}
This study is entitled the effect of competence on employee motivation Office of jambi province relationship. This study uses path analysis and t test in testing. Competence has a partial effect on motivation $(Y)$. The effect of competence on motivation is $4.7 \%$.
\end{abstract}

Keyword: competence, motivation

\section{PENDAHULUAN}

Era globalisasi dunia memberikan pengaruh di berbagai bidang, termasuk pengaruh terhadap perkembangan pendidikan di Indonesia sehingga diperlukan sumber daya manusia (SDM). Seperti yang diamanatkan dalam pembukaan Undang-Undang Dasar Negara Republik Indonesia Tahun 1945 menyatakan bahwa tujuan nasional adalah untuk melindungi segenap bangsa dan seluruh tumpah darah Indonesia dan untuk memajukan kesejahteraan umum, mencerdaskan kehidupan bangsa dan ikut melaksanakan ketertiban dunia berdasarkan kemerdekaan, perdamaian abadi, dan keadilan social. Untuk mewujudkan tujuan nasional tersebut, pendidikan merupakan faktor yang sangat menentukan.

Manusia merupakan sumber daya yang paling penting bagi perusahaan dalam usaha mencapai keberhasilan. Sumber daya ini menunjang Organisasi dengan bakat dan kreativitas. Betapapun sempurnanya aspek teknologi dan ekonomi, tanpa ditunjang dengan aspek manusia sulit kiranya tujuan-tujuan organisasi dapat dicapai, masyarakat telah menunjukkan perhatian yang meningkat terhadap aspek manusia tersebut, nilainilai manusia semakin diselaraskan dengan aspek teknologi maupun ekonomi.

Pada prinsipnya sumber daya manusia merupakan salah satu sumber daya yang menentukan organisasi. Yang mana sumber daya manusia dipahami sebagai kekuatan yang bersumber pada potensi manusia yang ada dalam organisasi dan merupakan modal dasar organisasi untuk melakukan aktivitas dalam mencapai tujuan. Jadi, manajemen sumber daya manusia adalah pendekatan terhadap manajemen manusia. Dimana pendekatan terhadap manajemen manusia tersebut didasarkan pada nilai manusia dalam hubungannya dengan organisasi.

Aktivitas untuk menentukan berhasil tidaknya suatu pekerjaan yang dilakukan organisasi diperlukan pengelolaan dan perencanaan manajemen yang baik. Manajemen menurut Hasibuan, (2008:9) adalah "ilmu dan seni mengatur proses pemanfaatan sumber daya manusia dan sumber-sumber lainnya secara efektif dan efisien untuk mencapai suatu tujuan tertentu". Sumber daya manusia merupakan hal yang sangat penting dalam kegiatan organisasi. Fathoni, (2006: 8) mengungkapkan bahwa "waktu, tenaga, dan kemampuannya benar-benar dapat dimanfaatkan secara optimal bagi kepentingan organisasi, maupun bagi kepentingan individu". Diperlukan adanya suatu pelatihan agar pegawai dapat melakukan aktivitas kerja dengan efektif sehingga sumber daya manusia dapat mencapai kinerja yang baik. Organisasi menurut pelaksanaannya perlu melakukan suatu penilaian kinerja pegawai. Kinerja merupakan jawaban dari berhasil tidaknya tujuan organisasi. Kinerja pegawai diketahui dari seberapa jauh pegawai melaksanakan tugas sesuai tanggung jawabnya. Menurut Mangkunegara (2009:67) "kinerja adalah hasil kerja secara kualitas dan kuantitas yang dicapai oleh seseorang pegawai dalam melaksanakan tugasnya sesuai dengan tanggungjawab yang diberikan kepadanya". Hasil kinerja yang baik salah satunya apabila pegawai mampu memberikan pelayanan yang baik kepada masyarakat. Kinerja juga bisa menjadi gambaran kualitas dari organisasi. Organisasi yang memiliki kinerja baik, tentu saja akan memiliki kualitas manajemen yang baik pula. Maka tidak bisa dipungkiri bahwa kinerja termasuk pula ke dalam hal yang sangat penting dalam mencapai tujuan organisasi.

Untuk mencapai kinerja yang baik, maka para pegawai harus memiliki kompetensi yang baik dalam menyelesaikan pekerjaan. Konsep kompetensi mulai menjadi tren dan banyak diperbincangkan sejak tahun 1993 dan saat ini menjadi sangat populer terutama di lingkungan perusahaan multinasional dan nasional yang modern. Menurut Edy Sutrisno (2009), Wood dan Payne mengemukakan istilah konsep kompetensi. Sebenarnya telah diperkenalkan sejak tahun 1982 oleh Richard Boyatzis seorang penulis manajemen asal Amerika Serikat dalam bukunya The Competent Manager. Peningkatan kemampuan merupakan strategi yang diarahkan untuk meningkatkan efisiensi, efektivitas dan sikap tanggap dalam rangka peningkatan kinerja organisasi secara keseluruhan. Adapun dimensi-dimensi dari peningkatan kemampuan ini dapat berupa upaya pengembangan sumber daya manusia, pengetahuan organisasi, dan reformasi kelembagaan. Dalam 
menghadapi perkembangan lingkungan organisasi, menuntut kesiapan sumber daya manusia organisasi untuk memiliki kemampuan dalam menjawab tantangan tersebut dengan menunujukkan kinerjanya melalui kegiatan-kegiatan dalam bidang tugas dan pekerjaannya dalam bidang organisasi.

Dalam rangka operasional, kompetensi tersebut membuat sumber daya manusia mampu menggali potensi sumber daya-sumber daya lainnya yang dillimiki oleh organisasi, mampu mengefektifkan dan mengefisiensi proses produksi di dalam organiasi serta mampu menghasilkan ouput yang sesuai dengan tujuan organisasi. Kesemuanya ini tentu saja pada akhirnya akan memberikan nilai tambah bagi organisasi secara keseluruhan. Kompetensi tersebut mampu terwujud melalui pendidikan dan pelatihan atau juga dari pengalaman selama bekerja pada bidang yang ia jalani.

Dinas Perhubungan Provinsi Jambi merupakan salah satu SKPD yang berada pada lingkungan tingkat provinsi. Dalam rangka mendukung dan menunjang pelaksanaan kegiatan operasional, Dinas Perhubungan Provinsi Jambi memiliki sumber daya manusisa yang mampu menyelesaikan tugas yang menjadi tanggung jawab masing-masing bagian. Dinas Perhubungan Provinsi Jambi memiliki tugas pokok dan fungsi berdasarkan Peraturan Gubernur Jambi Nomor 30 Tahun 2009 tentang Uraian Tugas dan Fungsi Dinas Perhubungan Provinsi Jambi memiliki tugas pokok dan fungsi adalah "Melaksanakan Kewenangan Desentralisasi dan Tugas Dekosentrasi di Bidang Perhubungan dan Sebagian Urusan Pemerintah Daerah Berdasarkan Azas Otonomi dan Tugas Pembantuan di Bidang Perhubungan."

\section{Tinjauan Pustaka \\ Kompetensi}

Menurut Boulter et al. (dalam Rosidah, 2003:11), kompetensi adalah karakteristik dasar dari seseorang yang memungkinkan pegawai mengeluarkan kinerja superior dalam pekerjaannya. Berdasarkan uraian di atas makna kompetensi mengandung bagian kepribadian yang mendalam dan melekat pada seseorang dengan perilaku yang dapat diprediksi pada berbagai keadaan dan tugas pekerjaan. Prediksi siapa yang berkinerja baik dan kurang baik dapat diukur dari kriteria atau standar yang digunakan.

Menurut Mc Acshan dalam Sutrisno (2010: 203) memberikan pengertian kompetensi sebagai pengetahuan, keterampilan, dan kemampuan yang dikuasai oleh seseorang yang telah menjadi bagian dari dirinya, sehingga ia dapat melakukan perilaku- perilaku kognitif, afektif, dan psikomotorik dengan sebaikbaiknya. Apabila kompetensi diartikan sama dengan kemampuan, maka dapat diartikan pengetahuan memahami tujuan bekerja, pengetahuan dalam melaksanakan kiat-kiat jitu dalam melaksanakan pekerjaan yang tepat dan baik, serta memahami betapa pentingnya disiplin dalam organisasi agar semua aturan dapat berjalan dengan baik.

Beberapa aspek yang terkandung dalam konsep kompetensi adalah sebagai berikut (Gordon dalam Sutrisno, 2010):

1. Pengetahuan (knowledge), yaitu kesadaran dalam bidang kognitif. Misalnya seorang karyawan mengetahui cara melakukan identifikasi belajar, dan bagaimana melakukan pembelajaran yang baik sesuai dengan kebutuhan yang ada di perusahaan.

2. Pemahaman (understanding), yaitu kedalaman kognitif, dan afektif yang dimiliki oleh individu. Misalnya, seorang karyawan dalam melaksanakan pembelajaran harus mempunyai pemahaman yang baik tentang karakteristik dan kondisi kerja secara efektif dan efisien.

3. Nilai (value), adalah suatu standar perilaku yang telah diyakini dan secara psikologis telah menyatu dalam diri seseorang. Misalnya, standar perilaku para karyawan dalam melaksanakan tugas (kejujuran, keterbukaan, demokratis, dan lain-lain).

4. Kemampuan ( $s k i l l)$, adalah sesuatu yang dimiliki oleh individu untuk melaksanakan tugas atau pekerjaan yang dibebankan kepada karyawan. Misalnya standar perilaku para karyawan dalam memilih metode kerja yang dianggap lebih efektif dan efisien.

5. Sikap (attitude), yaitu perasaan (senang-tidak senang, suka-tidak suka) atau reaksi terhadap suatu rangsangan yang datang dari luar. Misalnya reaksi terhadap krisis ekonomi, perasaan terhadap kenaikan gaji.

6. Minat (interest), adalah kecenderungan seseorang untuk melakukan suatu perbuatan. Misalnya melakukan suatu aktivitas kerja.

\section{Motivasi}

Istilah motivasi didefenisikan dalam berbagai cara oleh para ahli. Manulang (2004:12) mengatakan bahwa motivasi kerja tidak lain dari suatu yang menimbulkan dorongan atau semangat kerja. Dalam artian bahwa motivasi kerja tersebut adalah pendorong semangat kerja. Sementara itu, Mitchel (1985) mendefenisikan motivasi sebagai proses psikologis yang menyebabkan kemunculan, arah, kesinambungan dari tindakantindakan sukarela yang terarah pada tujuan.

Gibson et al (1996; 185 ) berpendapat bahwa motivasi adalah kekuatan yang mendorong seseorang karyawan yang menimbulkan dan mengarahkan prilaku. Dalam hal ini, kuat lemahnya motivasi kerja seseorang berpengaruh terhadap besar kecilnya prestasi yang diraih. Lebih jauh djelaskan, bahwa dalam kehidupan sehari-hari seseorang selalu mengadakan berbagai aktivitas, dimana salah satu aktivitas tersebut diwujudkan dalam gerakan-gerakan yang dinamakan kerja. Bekerja mengandung arti melaksanakan suatu tugas yang diakhiri dengan buah karya yang dapat dinikmati oleh orang yang bersangkutan. 
Lain halnya dengan Robbins dan Judge (2008) mendefenisikan motivasi sebagai kemauan untuk mengupayakan level-level usaha kerja yang tinggi menuju tujuan-tujuan keorganisasian, dikondisikan oleh kemampuan usaha kerja untuk memenuhi beberapa kebutuhan individual. Kebutuhan menurut defenisi ini adalah sebuah keadaan internal yang membuat akibatakibat atau hasil-hasil tertentu kelihatan menarik. Suatu kebutuhan yang tidak terpenuhi atau tidak terpuaskan akan menciptakan tensi yang mendorong gerakan di dalam diri individu. Gerakan ini kemudian menimbulkan sebuah prilaku berusaha untuk menemukan tujuantujuan tertentu yang jika tercapai akan menjurus pada pengurangan tensi.

Sementara itu, P. Robbins (2003) menjelaskan bahwa indikator dari motivasi dapat dilihat dari aspek :

1. Tanggap terhadap suatu tugas dan pekerjaan

2. Menyenangi pekerjaan

3. Memiliki keinginan untuk bekerja lebih banyak

4. Memiliki kreativitas dalam bekerja

5. Memperoleh kemauan dalam bekerja

\section{METODE PENELITIAN}

\section{Lokasi Penelitian}

Adapun objek penelitian dari penelitian ini adalah Kantor Dinas Perhubungan Provinsi Jambi.

\section{Populasi dan Sampel}

Populasi dalam penelitian ini adalah keseluruhan pegawai yang bekerja pada Kantor Dinas Perhubungan Provinsi Jambi yang tercatat yang berjumlah 172 orang. Kesemua populasi meliputi berbagai jenjang karir dan bidang pada Kantor Dinas Perhubungan Provinsi Jambi.

Berikut jumlah pegawai yang ada pada Kantor Dinas Perhubungan Provinsi Jambi:

Tabel 1. Jumlah Pegawai Kantor Dinas Perhubungan Provinsi Jambi

\begin{tabular}{lc}
\hline \multicolumn{1}{c}{ Bidang } & $\begin{array}{c}\text { Jumlah Pegawai } \\
\text { (orang) }\end{array}$ \\
\hline $\begin{array}{l}\text { Sekretariat } \\
\text { Perhubungan Darat dan }\end{array}$ & 17 \\
Perkeretaapian & 34 \\
Perhubungan Laut, Sungai, Danau, & 15 \\
Penyebrangan dan Udara & \\
Pengembangan Jaringan & 11 \\
Transportasi & 73 \\
UPTD & 22 \\
Pegawai tidak tetap & 172 \\
\multicolumn{1}{c}{ Total } &
\end{tabular}

Sumber : Dinas Perhubungan Provinsi Jambi

Untuk menentukan besarnya sampel yang akan dijadikan responden, peneliti mengacu pada pendapat Arikunto (2010). Arikunto dalam melakukan perhitungan ukuran sampel yang diperoleh menyatakan bahwa apabila populasi di bawah 100 maka diambil semuanya untuk dijadikan sampel. Tapi jika populasi di atas 100 maka diambil 10-25\% atau lebih. Dalam hal ini populasi berjumlah 172 orang, maka besaran sampel yang diambil sebesar $50 \%$ dari 172 orang menjadi 86 orang responden.

\section{Jenis dan Sumber Data}

Data primer adalah data yang diperoleh dengan cara penelitian dilapangan, yaitu data diperoleh dari para pegawai Kantor Dinas Perhubungan Provinsi Jambi dengan melakukan penyebaran kusioner. Data Sekunder adalah data yang diperoleh dengan cara mengadakan penelitian kepustakaan dan dokumen kepegawaian, dokumen kerja, dan dokumen lainnya yang berasal dari Kantor Dinas Perhubungan Provinsi Jambi.

Data-data yang didapat bersumber dari dalam (internal) Kantor Dinas Perhubungan Provinsi Jambi, seperti : data para pegawai, dan data lain yang mendukung. Sedangkan data eksternal bersumber dari literatur-literatur yang berkaitan dengan masalah yang diteliti.

\section{Metode Pengumpulan Data}

Dalam memperoleh data, digunakan metode survey yaitu dengan menggunakan perangkat kuesioner terstruktur yang diajukan pada responden. Format kuesioner terdiri dari dua bagian utama, bagian pertama menyangkut pertanyaan-pertanyaan umum mengenai karakteristik pegawai dan bagian kedua berisi pertanyaan masalah pokok penelitian. Item-item pertanyaan diantaranya adalah seperti telah dikemukakan sebelumnya. Pengumpulan data dilakukan dengan pertama-tama meminta kesediaan para responden untuk berpartisipasi dalam penelitian ini, kemudian menyampaikan perangkat kuesioner penelitian untuk diisi oleh responden.

\section{Tehnik Analisis Data}

Dalam menganalisis dan menginterpretasikan data dan informasi dalam penelitian ini, penulis menggunakan pendekatan analisa statistik/verifikatif.

\section{Path Analysis}

Untuk menjawab permasalahan menggunakan analisis jalur (Path Analysis) yang merupakan suatu metode pendekomposisian korelasi ke dalam bagianbagian yang berbeda untuk menginterprestasikan suatu pengaruh/efek. Metode Path Analysis ini juga digunakan untuk menelaah hubungan antara model kausal yang dirumuskan atas dasar pertimbangan teoritis dan pengetahuan tertentu. Hubungan kausal selain didasarkan pada data, juga didasarkan pada pengetahuan, perumusan hipotesis dan analisis logis, sehingga dapat dikatakan Path Analysis ini dapat digunakan untuk menguji seperangkat hipotesis kausal serta untuk menafsirkan hubungan tersebut. Adapun hubungan struktural antar variabel kompetensi dan motivasi dapat dijelaskan pada gambar dibawah ini : 


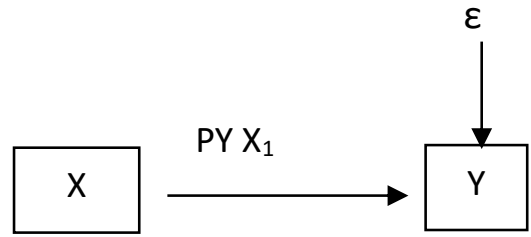

Gambar 1. Hubungan Struktural Antara X Terhadap Y

Keterangan :

$\begin{array}{ll}\mathrm{X} & : \text { Kompetensi } \\ \mathrm{Y} & : \text { Motivasi }\end{array}$

$\mathrm{P}_{\mathrm{YX} 1}$ dan $\mathrm{P}_{\mathrm{YX} 2}$ adalah koefisien jalur dan $\mathrm{r}_{\mathrm{X} 1 \mathrm{X} 2}$ adalah koefisien korelasi, maka persamaan struktural untuk diagram jalur diatas dinyatakan dengan :

$\mathbf{Y}=\mathbf{P}_{\mathbf{Y X}} \mathbf{X}+\varepsilon$

Sedangkan pengaruh antar variabel diatas dinyatakan dengan persamaan sebagai berikut:

Pengaruh $\mathrm{X}$ terhadap $\mathrm{Y}$ : Pengaruh langsung : X $\rightarrow \mathrm{Y}=\left(\mathrm{P}_{\mathrm{YX}}\right) \mathrm{x}\left(\mathrm{P}_{\mathrm{YX}}\right)$

\section{Uji $t$}

Uji t digunkan untuk mengkaji koefisien regresi secara individual yaitu antara variabel independen dengan variabel dependen. Adapun langkah-langkahnya sebagai berikut :

1. Menentukan Hipotesis

H0 : bi =0, (Tidak ada pengaruh yang signifikan antara variabel independen (x) terhadap variabel dependent $(\mathrm{y}))$

H1 : bi $\neq 0$, (Ada pengaruh yang signifikan antara variabel independen ( $\mathrm{x}$ ) terhadap variabel dependen (y) )

2. Menentukan tingkat signifikansi

Diuji dengan tingkat signifikansi ( a ) sebesar 0.05.

3. Kesimpulan

$\mathrm{H} 0$ diterima apabila $-\mathrm{t}$ tabel $<\mathrm{t}$ hitung $<\mathrm{t}$ tabel

$\mathrm{HO}$ di tolak apabila $\mathrm{t}$ hitung $>\mathrm{t}$ tabel atau $\mathrm{t}$ hitung $<-$ t tabel.

\section{HASIL DAN PEMBAHASAN}

\section{Analisis Jalur Pengaruh Kompetensi terhadap Motivasi}

Dalam analisis ini, diperlukan nilai koefisien jalur kompetensi terhadap motivasi. Berikut koefisien jalur dalam penelitian ini :

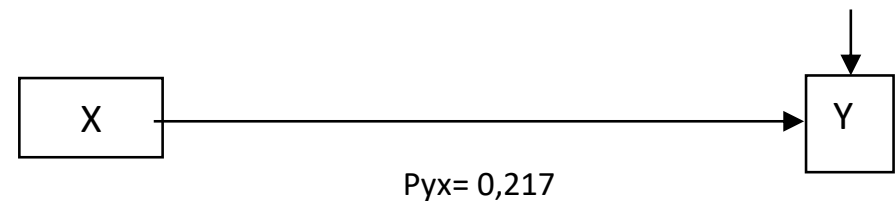

Gambar 2. Koefisien Jalur

Pengaruh Motivasi $\left(\mathrm{X}_{1}\right)$ terhadap Kinerja $(\mathrm{Y})$

$$
\begin{aligned}
\mathrm{X} \longrightarrow \mathrm{Y} & =(\mathrm{pYX})(\mathrm{pYX}) \\
& =0,217 \times 0,217 \\
& =0,047 \\
& =4,7 \%
\end{aligned}
$$

Dari rincian diatas pengaruh kompetensi $(\mathrm{X})$ terhadap Motivasi (Y) sebesar $4,7 \%$.

Variabel Residu

$$
\begin{aligned}
\mathrm{Py}_{1} & =\sqrt{1-\mathrm{R}^{2} \mathrm{Y}(\mathrm{X})} \\
& =\sqrt{1-0,047} \\
& =0,976
\end{aligned}
$$

Jadi persamaan struktur adalah sebagai berikut:

$$
\begin{aligned}
\mathrm{Y} & =\mathrm{Pyx}_{1} \mathrm{X} 1+\mathrm{Pyx}_{2} \mathrm{X} 2+\varepsilon_{1} \\
& =0,217 \mathrm{X}+0,976
\end{aligned}
$$

\section{Pengujian hipotesis}

pengaruh kompetensi terhadap motivasi yang ada membuktikan bahwa kompetensi terhadap motivasi jika dilihat dari nilai t hitung yaitu sebesar 1,863 dimana nilai $\mathrm{t}$ tabel pada derajat kesalahan $5 \%$. sebesar 1,66320 berarti variabel kompetensi memberi pengaruh secara parsial terhadap variabel motivasi.

\section{SIMPULAN}

Berdasarkan pada pembahasan dapat ditarik kesimpulan bahwa kompetensi memiliki pengaruh secara parsial terhadap motivasi (Y). Pengaruh kompetensi terhadap motivasi sebesar $4,7 \%$.

\section{DAFTAR PUSTAKA}

Anak Agung Ngurah Bagus Dhermawan, dkk. 2012. Pengaruh Motivasi, Lingkungan Kerja, Kompetensi, Dan Kompensasi Terhadap Kepuasan Kerja Dan Kinerja Pegawai Di Lingkungan Kantor Dinas Pekerjaan Umum Provinsi Bali. Bali : OJS Universitas Udayana

Fred, Luthans. 1998. Organizational Behavior: Instuctor's Resources Manual and Test Bank. New York: International Book Company

Fuad Mas'ud. 2004. Survei Diagnosis Organisasional. Semarang : Badan Penerbit Universitas Diponegoro

Gibson, James L. et al. 2004. Organisasi : Perilaku Struktur Dan Proses. Alih bahasa : Ir. Hunuk Adiarni,MM. Jakarta : Bina Rupa Aksara

Ghozali, Imam. 2011. Aplikasi Analisis Multivariate dengan Program SPSS. Semarang: Badan Penerbit Universitas Diponegoro.

Gomes, Faustino Cardoso. 2003. Manajemen Sumber 
Daya Manusia. Yogyakarta : ANDI

Handoko, T. Hani. 2003. Manajemen. Yogyakarta: BPFE.

dan Sumber Daya Manusia. Yogyakarta: BPFE.

Hartanto, L. 2000. Manajemen Personalia. Jakarta: PT. Radjagrafindo

Hasibuan, Malayu. 2007. Organisasi dan Motivasi Dasar Peningkatan Produktivitas. Jakarta: PT. Bumi Aksara. 2008. Manajemen Sumber Daya Manusia. Jakarta: Bumi Aksara.

Hutapea, Parulian dan Nurianna Thoha. 2008. Kompetensi Plus. PT. Gramedia Pustaka Utama: Jakarta

Kaswan. 2012. Manajemen Sumber Daya Manusia untuk Keunggulan Bersaing Organisasi. Yogyakarta: Graha Ilmu.

Kreitner, Robert dan Kinicki, Angelo. 2005. Perilaku Organisasi. Jakarta: Salemba Empat

Lund Daulatram. 2003. Organization Culture and Job Satisfaction. Journal of business and Industrial Marketing. Vol 18 No 32003 pp.219-236.

Lupiyoadi, Hamdani. 2006. Manajemen Pemasaran Jasa, Edisi Kedua. Jakarta : Penerbit Salemba Empat

Mangkunegara Anwar.P (2000). Manajemen Kepegawaian Dan Sumber Daya Manusia, Bandung

. 2009. Manajemen Sumber Daya Manusia Perusahaan. Bandung: PT. Remaja Rosda Karya.

Mariam, Rani. 2009. Pengaruh Gaya Kepemimpinan Dan Budaya Organisasi Terhadap Kinerja Karyawan Melalui Kepuasan Kerja Karyawan Sebagai Variabel Intervening Studi Pada Kantor Pusat PT.Asuransi Jasa Indonesia (Persero). Semarang: UNDIP

Moenir. 2003. Pendekatan Manusiawi dan Organisasi terhadap Pembinaan Kepegawaian. Jakarta: PT Gunung Agung.

Moeheriono. 2009. Pengukuran Kinerja Berbasis Kompetensi. Bogor. Ghalia Indonesia

Riduwan. 2012. Skala Pengukuran Variabel-Variabel Penelitian. Bandung: Alfabeta

Robbins SP dan Judge. 2002. Perilaku Organisasi. Jakarta : Salemba Empat

Rosidah dan Ambar T. Sulistiyani. 2003. Manajemen Sumber Daya Manusia. Cetakan. Pertama. Penerbit Graha Ilmu.

Siagian, Sondang P. 2003.Teori dan Praktek Kepemimpinan, Jakarta: PT. RINEKA CIPTA

Sudarmanto. 2009. Kinerja dan Pengembangan Kompetensi SDM. Yogyakarta: Pustaka Pelajar.

Sudrajat. Subana M. dan Marsetiyo Rahardi. 2000. Statistik Pendidikan. Pustaka: Bandung

Sugiyono. 2010. Metode Penelitian Kuantitatif
Kualitatif dan $R \& D$. Bandung: Alfabeta.

Suharsimi, Arikunto. 2010. Prosedur Penelitian Suatu Pendekatan Praktik. Jakarta: Rineka Cipta

Sunyoto, Danang. 2013. Teori, Kuesioner dan Analisis Data Sumber Daya Manusia. Yogyakarta: CAPS.

Supriyanto, Yudi. 2015. Kompetensi Dan Komitmen Organisasional Terhadap Kepuasan Kerja Dan Kinerja Karyawan Koperasi. Prosiding Seminar Nasional 9 Mei 2015

Sutrisno, Edy. 2010. Manajemen Sumber Daya Manusia. Jakarta : Kencana Prenada Media Group

Umar, Husein. 2002. Metode Riset Komunikasi Organisasi. Jakarta: PT Gramedia Pustaka Utama. Wibowo. 2007. Manajemen Kinerja. PT. Raja Grafindo Parsada: Jakarta 